\title{
Dark Alchemy: The Films of Jan Švankmajer
}

\author{
By Jan Uhde
}

Fall 1995 Issue of KINEMA

\section{The ARCIMBOLDO OF ANIMATION}

Peter Hames' Dark Alchemy is the first book publication on the Czech master animator Jan Švankmajer. This may sound surprising, since Svankmajer, a pre-eminent Czech artist has produced twenty-six shorts and two features over the last three decades and is the recipient of numerous international festival prizes and awards. Despite the critical acclaim, his achievements have remained in partial obscurity.

There may be more than one reason for this peculiarity: most of Švankmajer's artistic career has coincided with the totalitarian rule in the former Czechoslovakia. The Communist regime was not at all interested in encouraging or promoting an artist whose work represented an opposing view to the government's cultural ideology and practice, and was thus barely tolerated by the authorities.

In the West European countries and across the Atlantic, it was Svankmajer's eccentric style, experimentation and evident reluctance to genuflect before mediocre audiences which prevented his films from being widely distributed or televised. Also, with two recent exceptions (Alice, 1987 and Faust, 1994) Svankmajer restricted himself to short film production; this fact alone is a significant distribution handicap for any filmmaker.

Peter Hames, the editor of Dark Alchemy, is a well-known authority on Czech cinema and the author of The Czechoslovak New Wave. He emphasizes that his book on Svankmajer is "something other than the conventional monograph." Besides Hames' own article, his book includes contributions by three competent Svankmajer's scholars, including the Czech Surrealist, and editor of magazine Analogon, Frantisek Dryje.

The introductory essay written by Hames provides mainly information on some of the philosophical, historical, and artistic contexts within which Svankmajer and his work has developed. At least a cursory knowledge of these facts, including the influence of Czech Surrealism upon the artist, is essential for proper understanding of Svankmajer's opus. Much of this information, however, can also be found in the above-mentioned book on Czechoslovak New Wave.

Hames has also included his interview with Svankmajer which offers a meaningful insight into the latter's personality, aesthetic influences, and idiosyncrasies. For example, it reveals that the artist's fascination with the puppet and marionette reaches back to his formative years spent at the Prague Theatre Academy (DAMU) when he was a student in the Puppetry Faculty.

Svankmajer's involvement with this art form (puppetry has had a deep historical significance in Czech culture) may explain his self-admitted "weakness for the decayed genres of folk art: puppets ... old toys, shooting ranges, mechanical fairground targets and ... black novels (in film -- Georges Méliès, Louis Feuillade)."

Readers of Sight and Sound and other film periodicals may be familiar with Michael O'Pray's erudite writings on Svankmajer through which he has introduced this artist to film audiences in Britain and elsewhere. O'Pray's thorough article in Dark Alchemy examines the director's link with the artistic style of the 16th century Mannerists, particularly that of the Italian painter Giuseppe Arcimboldo. Arcimboldo greatly contributed to the creative cultural atmosphere of sixteenth century Prague, then the capital of Rudolf II's Holy Roman Empire. Svankmajer's visual style and numerous suggestions in his films point to the Mannerist art -- a fascinating era linking the Renaissance with the Baroque. In the Prague of that period, the South of Europe met with the North; the nascent scientific rationalism and technology were blending with spiritual and magical elements (the alchemists, Faustian and Golem legends, medical experiments, etc.).

Svankmajer's "Surrealist connection" is well known. In his essay, Frantisek Dryje comments on the filmmaker from this point of view; among other materials, he includes excerpts from articles and discussions on the director's work written over the years by members of the (still active) Prague Surrealist group. "The force of imagination allows us the privilege of casting doubt on every intellectual and emotional convention, and asserts the supremacy of transformation as an existential situation, a state which, looked at with rational 
logic, is impossible and therefore irrational." Dryje's words accurately characterise Svankmajer's perspective -- both as a filmmaker and visual artist.

Roger Cardinal's contribution is the shortest but probably the one most focused on a specific stylistic aspect. It discusses the role of objects in Svankmajer's early films (although quite a considerable amount of space is allotted to the discussion of the filmmaker's 1983 short Dimensions of Dialogue).

Dark Alchemy's texts are well annotated; they are complemented by a full Jan Svankmajer filmography, a general bibliography, an index, as well as thirty black-and-white stills from Svankmajer's films. The intricacies of Czech spelling present no problems in Hames' book; such meticulous editing remains quite rare in English-language publications (including scholarly texts). Last but not least, the availability of Svankmajer's films on videocassettes is also indicated.

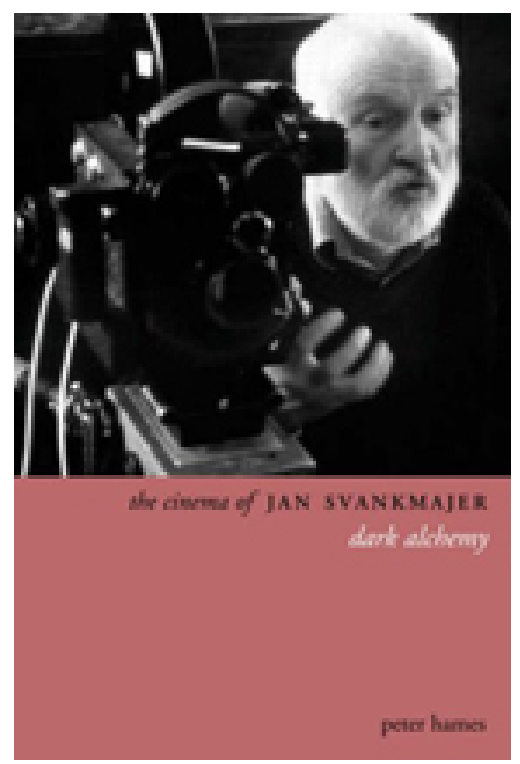

Figure 1: TITLE: Dark Alchemy: The Films of Jan Švankmajer. Peter Hames (ed). I BY: Peter Hames 9 PUBLISHER: Westport: Praeger \ YEAR: 1995 ๆ PAGES: 202pp, Ill. ๆ ISBN: 0-275-95299-1. Paper

\section{Author Information}

Jan UHDE is Professor Emer. (Film Studies) at the University of Waterloo, Ontario, Canada. Born in Brno, Czech Republic. Graduated (MA) from the Faculty of Arts, Masaryk University, Brno; PhD received at the University of Waterloo, Ontario, Canada. He taught at the University of Waterloo (1970-2012) where he founded a General and Honours BA program in Film Studies at the Department of Fine Arts.

Publications: Latent Images: Film in Singapore Second edition, with Yvonne Ng Uhde (Ridge Books, National University Press of Singapore, 2010); Latent Images: Film in Singapore, with Yvonne Ng Uhde (Oxford University Press, 2000); Latent Images: Film in Singapore CD-ROM (2003, co-author); Vision and Persistence: Twenty Years of the Ontario Film Institute (University of Waterloo Press, 1990) and Ontario Film Institute Programming Activities Index 1969-1989 (Toronto: Ontario Science Centre, 1990). He co-edited the Place in Space: Human Culture in Landscape (Proceedings from the Second International Conference of the Working Group "Culture and Landscape" of the International Association of Landscape Ecology, Pudoc Scientific Publishers, Wageningen, Holland, 1993). Jan Uhde has published articles and reviews in several countries (including Canada, USA, Germany, Italy), participated in international juries at film festivals and presented papers at international conferences in North America and Europe. In 1998/99, he was a visiting researcher at the School for Film and Media Studies, Ngee Ann Polytechnic, Singapore. 
His professional and research interests focus on Singapore cinema; the identification and distancing mechanisms of the film viewer; the non-authored modifications and manipulation of films; and specific aspects of film history, including the Central European cinema.

He founded KINEMA in 1993. 